\title{
Sensory Evaluation Of Wet Noodle Products Added With Moringa Oleifera Flour With Different Concentrations
}

\author{
Author \\ Sutrisno Adi Prayitno (Orcid ID. 0000-0002-5116-166X), \\ Nur Agustin Mardiana (Orcid ID. 0000-0003-2013-3225), \\ Nurthalita Alifia Rochma (Orcid ID. 0000-0002-5722-9389) \\ Correspondence \\ Department of Food Technology, Faculty of Agriculture, University of Muhammadiyah Gresik \\ sutrisnoadi2007@umg.ac.id
}

\begin{abstract}
Noodles are foods that are often consumed by the community as a substitute for rice carbohydrates. Generally, noodles are only made from wheat flour which only has a carbohydrate source. Nutritional needs are not only carbohydrates but also fats and proteins and mineral groups. The purpose of this study was to determine the sensory properties of wet noodle products added with Moringa oleifera leaf flour with various concentrations. The concentration of Moringa oleifera flour compared to wheat flour used in making wet noodles was 0\%:100\%, 5\%:95\%, 10\%:90\%, and 15\%:85\%. The analytical parameters used are taste, color, aroma, and texture. The panelists used were untrained panelists. Panelists were asked to analyze the hedonic test on the sample of wet noodles served. The results showed that the concentration of Moringa oleifera leaf flour and wheat flour had an influenced on the hedonic level of each parameter in wet noodles. Overall, the best organoleptic value for wet noodles added with Moringa oleifera leaf flour was 5\% and wheat flour 95\% which had an average hedonic level of 103.06 colors, 102.34 aromas, 103.63 taste, and 100.71 on texture. While the lowest hedonic value was in the ratio of Moringa oleifera leaf flour and wheat flour of 15\%: $85 \%$ with hedonic results 32.09 colors, 29.44 aromas, 29.89 taste, and 38.37 in texture. So it can be concluded that Moringa oleifera leaf flour is good in organoleptic substitution by $5 \%$. Similar studies are needed with different or smaller concentrations of Moringa oleifera leaf powder.
\end{abstract}

Keywords : Noodles, Moringa oleifera, Hedonic Test, Sensory

Received: 13 June 2021. Accepted: 24 June 2021

\section{Introduction}

Processed flour products that are very popular with the community are noodles which are usually used as a substitute for rice as the main food. The advantage of instant noodles, in general, is that it is easy to serve with a delicious taste and practical in serving. In addition, it also has an affordable price and a longer shelf life (Ebtihal et al., 2019). Consumption of foods that are low in protein is inappropriate, or even not balanced by the addition of vegetables or groups of plant materials. This is related to the nutritional needs that cannot be met only from one type of food or one type of nutrition (Susilowati and Rizal, 2017).
Noodle products are currently experiencing development, especially the variation of the mixture used. The manufacture of noodles can add vegetables, tubers, or legumes whose purpose is to improve the nutritional status of the noodle product. Noodles generally have low fat and sodium content but have a high carbohydrate content. Not only noodles, products that are high in carbohydrates are also found in potatoes, corn, or soybean flour (Olorunsogo et al., 2019).

Nutrient needs in noodles will be better and increase if the noodle processing is added with vegetable or vegetable ingredients. Plants that can be used to improve nutritional status in noodle products 
are Moringa oleifera leaves. Moringa oleifera leaves contain high levels of protein and groups of macronutrient compounds such as $\mathrm{Ca}, \mathrm{K}, \mathrm{Fe}, \mathrm{Mg}, \mathrm{Mn}, \mathrm{Cu}$, phenolic compounds, and vitamins A, B, C, and D (Aslam et al., 2005: Thurber and Fahey., 2009: Olson et al., 2016). Vitamins A, C, and D in Moringa oleifera leave to act as good provitamins (Adi et al., 2019). The addition of Moringa powder also affects the increase in protein and mineral levels (Chandra et al., 2019). This is also supported by the research of Adi et al., (2019) which said that the addition of $10 \%$ Moringa oleifera increased protein status, vitamins $\mathrm{A}, \mathrm{C}, \mathrm{Ca}$, and Zinc. In addition, from the research of Orisa and Ukpong (2019), adding Moringa oleifera leaves as a substitute material also increases the ash, fiber, fat, and protein content.

In addition to nutritional parameters, a good food product must also have a good visual impression. Food products are also influenced by the appearance (appearance) and good texture as well as the authenticity of the ingredients and the acceptability of the product by consumers (Galmarini, 2020). A consumer can accept or reject the food being sold depending on the acceptability of the product served, including the appearance, taste, color, or texture of the product (Willett et al., 2019). In analyzing the quality of a product, it is necessary to combine analysis with instrumental measurement and sensory analysis that uses the human senses (Kohyama, 2020). Sensory in food products can be shown in several parameters, including the quality of taste, color, aroma, or texture (Jeltema et al., 2015: Peyron et al., 2017).

\section{Methods}

The ingredients used in making noodles are wheat flour, Moringa oleifera leaf flour, water, salt, eggs, and garlic. All the ingredients are then mixed to make a dough. In this study, 4 proportions of Moringa oleifera leaf flour and wheat flour were used, namely $0 \%: 100 \%, 5 \%: 95 \%, 10 \%: 90 \%$, and 15\%: $85 \%$. The noodles that have been made are then analyzed through an organoleptic test or a sensory test. The scale used in the sensory analysis by the panelists was 4: like very much, 3: like 2: dislike, 1: dislike very much. The analysis involved untrained panelists. Sensory analysis of the product includes parameters of taste, color, aroma, and texture. The data obtained from the panel, then analyzed by SPSS using the Kruskal Wallis test.

\section{Result and Discussion}

Noodle food products are foods that are favored by the community. The use of natural ingredients to improve nutrition and sensory in noodle products is needed in its processing. The addition of Moringa oleifera leaf flour in the manufacture of wet noodles is the right choice to improve the nutritional and sensory status of the product. The main purpose of adding Moringa oleifera leaf flour is to increase product acceptance by consumers. The wet noodle products that have been made were analyzed by hedonic tests on the panelists. The results of the sensory analysis were analyzed by Kruskal Wallis and can be seen in the following table 1 :

Table 1. Results of the sensory analysis

\begin{tabular}{cccccc}
\hline \multirow{2}{*}{$\begin{array}{c}\text { Treat } \\
\text { ment }\end{array}$} & \multicolumn{4}{c}{ Parameter } & asymp. \\
\cline { 2 - 5 } & Taste & Color & Aroma & Texture & Sig \\
\hline P0 & 77.70 & 76.91 & 81.17 & 75.11 & 0.000 \\
P1 & 103.63 & 103.06 & 102.34 & 100.71 & 0.000 \\
P2 & 70.79 & 69.94 & 69.04 & 67.80 & 0.000 \\
P3 & 28.89 & 32.09 & 29.44 & 38.37 & 0.000 \\
\hline
\end{tabular}

In the hedonic test, 35 panelists were used untrained. Panelists were asked to rate the wet noodle product, by including a code on the sample in the form of P0, P1, P2, and $\mathrm{P} 3$. In the hedonic analysis, the panelists did not know the concentration of Moringa oleifera leaf flour and wheat flour used, but only assigned a code to the sample presented. The purpose of not giving information on the concentration of Moringa oleifera leaf flour 
and wheat flour is so that the panelists do not suspect the concentration of the product. Because the purpose of the hedonic test is to ask the panelists to give a value according to the impression received on the product when the sample analysis is carried out. The following is the result of sensory abalysis on the noodles added with moringa oleifera flour.

\section{Flavor}

Taste is very important in the assessment of food products. The human organ that plays a role in assessing taste is the tongue. The tongue has receptors that can distinguish tastes in food ingredients. This is under the statement of Saniyah et al (2018) which states that the taste of food products can be detected by the presence of the tongue, because the tongue has a good response to flavors in food in the form of sour, sweet, salty and bitter. Taste is considered an important factor in determining a decision to accept or reject a food or beverage product.

From table 1, it is known that the taste value based on the results of the analysis shows the Asymp value. Sig $<0.05$ which means that there are differences in the taste value of wet noodles due to the addition of Moringa oleifera flour with different concentrations. Making wet noodles with a ratio of 5\% Moringa oleifera flour and 95\% wheat flour has the highest hedonic test value of 103.63 and shows the most preferred proportion. The use of Moringa oleifera flour at $15 \%$ gives a very low yield which can be concluded that the product is not liked by the panelists. The increasing amount of Moringa oleifera flour added to the dough results in a slightly bitter taste. Thus, the increase in the concentration of Moringa oleifera flour affects the level of taste preference, ie panelists tend not to like the taste. The increase in the concentration of Moringa oleifera flour gives an after-taste effect on the noodle product.

\section{Aroma}

Assessment of aroma in a food or beverage product can be hedonic test using a scoring scale (Saniyah et al., 2018). The aroma of the noodles with the addition of Moringa oleifera flour gives a different visual.
This aroma appears because Moringa oleifera leaves contain compounds that are easy to evaporate, so that when added to the noodle mixture it will evaporate and can be felt by a panelist. Moringa oleifera leaves have compounds with high volatility (easy to evaporate). Volatile compounds are easy to reach the olfactory system (olfactory). Aromatic compounds can be found in all plants or fruits that are often used in the food industry as a flavor in manufactured foods and beverages.

In the manufacture of the noodles, as a control, the highest aroma preference value was 81.17 , while in the treatment with the addition of Moringa oleifera leaf flour at the lowest concentration of $5 \%$ according to the hedonic test, panelists tended to like the aroma of the noodles. However, the increase in the concentration of Moringa oleifera flour by $10 \%$ and $15 \%$ by hedonic test panelists did not like the aroma of the noodles. In the treatment with the addition of 5\% Moringa oleifera leaf flour by hedonic test, it obtained a higher value of 102.34, along with the increase in the concentration of Moringa oleifera leaf flour giving the panelists' preference for aroma decreased. The increase in concentration makes the noodle product have a sharp aroma like herbal medicine. The hedonic test gives the level of liking for the unfavorable aroma is the concentration of Moringa oleifera leaf flour by $15 \%$ with a value of 29.44 (lowest compared to other concentrations). This shows a concentration of $5 \%$ can be a recommendation in the manufacture of noodle products and so on. From table 1, it shows that the aroma value in the analysis results shows the Asymp value. Sig $<0.05$ which means that there are differences in the aroma value of the wet noodles produced due to the addition of Moringa oleifera flour with different concentrations. The higher the concentration of Moringa oleifera leaf flour gave the hedonic effect on the panelists, which tended to dislike the noodles product.

\section{Color}

Color is a vision in food or beverage products that can be quickly and directly detected by the organ of vision (eyes). The 
color of food and drink gives the impression of attraction. Based on the results of the hedonic test, the Kruskal Wallis test showed the Asymp value. Sig $<0.05$ which means that there is a relationship or there is a difference in the color value of the resulting noodle product. The use of Moringa oleifera leaf powder had a significant effect on each treatment. The higher the concentration of Moringa oleifera leaf flour (\% used), the hedonic test value decreased. The treatment at P1 with the smallest amount of Moringa oleifera leaf powder gave the highest hedonic test value for color 103.06 (most preferred). While at a concentration of $10 \%$ the hedonic test value is 69.94 and at a concentration of $15 \%$ it produces a value of 69.94 which both (10 and 15\%) have different values on the hedonic test by a panelist. The higher the concentration of Moringa oleifera leaf flour used in the dough, the less attractive the color of the noodles will be. The resulting color is getting stronger.

\section{Texture}

The texture of the resulting noodles has a different value. The texture is the state of the product in a hard, rough, solid, liquid, softor easil, y damaged condition (Prayitno and Rahma, 2020). Based on the results of the hedonic test, the Kruskal Wallis test showed the Asymp value. Sig $<0.05$ which means that there is a relationship or there is a difference in the texture value of the resulting noodle product. The increasing concentration of Moringa oleifera leaf flour used in the dough gives a higher level of texture to the noodle product. Panelists preferred the addition of 5\% Moringa oleifera leaf powder concentration compared to the addition of $10 \%$ and $15 \%$. The texture of the noodles, the noodles that were treated with the addition of Moringa oleifera leaf flour had a significant difference. The use of wheat flour concentration also affects the texture of the noodles. This study using wheat flour with high protein, which allows the high gluten in the flour. So, if the concentration of Moringa oleifera leaf flour used is lower, it means that a high concentration of wheat flour will give the results a more chewy or elastic texture. This elastic level is influenced by the presence of gluten in wheat flour while Moringa oleifera leaves do not have gluten compounds (Trisnawati and Nisa, 2014) so that if used in high concentrations it will reduce the degree of elasticity in noodles because the gluten in wheat flour decreases.

\section{Conclusion}

From the results of the study, it can be concluded that the increasing concentration of Moringa oleifera leaf flour used has a significant effect on the sensory properties of noodle products. The recommended concentration for making noodles is $5 \%$. Further research needs to be carried out using a lower concentration of Moringa oleifera leaf powder below $5 \%$.

\section{References}

Adi AC., Qonita R and Agnesia NA. (2019) The Acceptance and Nutritional Value of Crispy noodles Supplemented with moringa oleifera as a functional snack for children in food Insecure Area. Prev. Nutrient. Food Science. 2019; 24(4):387392.

https://doi.org/10.3746/pnf.2019.24.4.387

Aslam, M., Anwar, F., Nadeem, R., Rashid, U., Kazi, TG, and Nadeem, M. (2005). Mineral composition of Moringa oleifera leaves and pods from different regions of Punjab, Pakistan. Asian J. Plant Sci. 4, 417-421. doi:10.3923/ajps.2005417.421

Chandra S., Pradeep D., Arti., Anjana and LP Shinde. (2019). Significance of Moringa Noodles for Increasing Breast Milk. Int.Res.J.Nutr., 1(1):6-9

Ebtihal, YK, Hafez, DA, and Sh. Ali, W. (2018). "Fortification of Instant Noodles Using Brassica oleracea to High Nutrition Value and Lowering Diabetics in Rats." Australian Journal of Basic and Applied Sciences 11 (5): 210-8. 
Galmarini, MV (2020). The role of sensory science in the evaluation of food pairing. Current Opinion in Food Science

Jeltema, M., Beckley, J., and Vahalik, J. (2015). Model for understanding consumer textural food choices. Food Science \& Nutrition $\quad 3$ : 202-212. https://doi.org/10.1002/fsn3.205.

Kohyama, K. (2020). Food Texture-sensory evaluation and instrumental measurement. Textural characteristics of world foods, 113.

Olson, ME, Sankaran, RP, Fahey, JW, Grusak, MA, Odee, D., and Nouman, (2016). Leaf protein and mineral concentrations across the "Miracle Tree" genus moringa. PLoS ONE 11:e0159782. DOI: 10.1371/journal.pone.0159782

Olorunsogo, ST, Adebayo, SE, Orhevba, BA, and Awoyinka, TB 2019. "Physicochemical Properties of Instant Noodles Produced from Blends of Sweet Potato, Soybean and Corn Flour." Food Research 3 (5): 391-9.

Orisa CA and Ukpong SU. (2019). Proximate and Mineral Compositions of Noodles Made from Triticum durum, Digitaria exilis, Vigna unguiculata Flour and Moringa oleifera Powder. Journal of Food Science and Engineering 9 (2019) 276-286. DOI: 10.17265/2159-5828/2019.07.003

Peyron, MA, Woda, A., Bourdiol, P. et al. (2017). age-related changes in mastication.Journal of Oral Rehabilitation 44:299-312. https://doi.org/10.1111/joor.12478.

Prayitno, SA, \& Rahma, A. (2020). The sensory evaluation on pumpkin ice cream that was formulated by red dragon fruit. Food Science and Technology Journal (Foodscitech), 2(2), 1-7. Saniyah, M., Kurniati, AR, Tazhkira, A., Ma'sumah, D., Sari, IP, Agnesia, D., \& Prayitno, SA (2018). Organoleptic Quality of Yellow Sweet Potato Tape (Ipomoea batatas L) due to Difference in Yeast Concentration (Saccharomyces cerevisiae). Foodscitech, 1(2), 35-43
Susilowati, Moch. Fahrur Rizal. (2017). Influence of Addition of Moringaoleifera Lam Leaves Flour to Mocaf-Based Noodles. Advances in Social Science, Education and Humanities Research (ASSEHR), volume 112. p 126-129.

Thurber, MD, and Fahey, JW (2009). Adoption of Moringa oleifera to combat

under-nutrition viewed through the lens of the "Diffusion of Innovations" theory. Ecol. Food Nuts. 48, 212-225. DOI: 10.1080/03670240902794598

Trisnawati, MI, \& Nisa, FC (2014). Effect of Addition of Moringa Leaf Protein Concentrate and Carrageenan on the Quality of Mocaf Substituted Dry Noodles [In Press January 2015]. Journal of Food and Agroindustry, 3(1), 237-247.

Willett W, Rockstro“m J, Loken B, Springmann M, Lang $\mathrm{T}$, Vermeulen S, Garnett $\mathrm{T}$, Tilman D, DeClerck F, Wood A. (2019): Food in the Anthropocene: the EATLancet Commission on healthy diets from sustainable food systems. The Lancet 2019, 393:447- 492 